\title{
Исследование потребительских свойств вина из ягод рябины бузинолистной
}

\author{
Майя Благонравова
}

Камчатский государственный технический университет, г. Петропавловск-Камчатский, Россия

\author{
Информация о статье \\ Поступила в редакцию: \\ 07.12 .2018 \\ Принята \\ к опубликованию: \\ 21.07.2019 \\ УДК 663.35 \\ JEL Q23
}

\section{Ключевые слова:}

вино, рябина бузинолистная, качество, органолептические показатели, профилограммы, химические показатели

\section{Keywords:}

wine, Rowan elderberry, quality, organoleptic characteristics, profilograms, chemical indicators

\begin{abstract}
Аннотация
В статье приводятся результаты оченки качества вина из рябины бузинолистной. Представлена технологическая схема производства. Органолептическую оценку проводили профильным методом и методом балльных шкал. Установлено, что вино из рябины имеет коричневый ивет с плодовым вкусом, умеренной спиртуозностью и бархатистой терпкостью. Вкус вина характеризуется как свежий, умеренный и гармоничный, с долгим приятным послевкусием. По химическим показателям (объемная доля этилового спирта, массовая кониентрачия сахаров, массовая концентрация титруемых кислот, массовая концентрация остаточного экстракта) вино полностью соответствует требованиям стандарта к винам столовым полусухим.
\end{abstract}

Research of Consumer Properties of Wine from the Berries of Mountain Ash Businessthey

Maya Blagonravova

\section{Abstract}

The article presents the results of the quality assessment of wine from Rowan businesses. The expediency of using Rowan berries for wine production is proved. The results of the study of consumer demand. The techno-logical scheme of production is resulted. The conducted research allowed to establish that the development of wine technology from Kamchatka raw materials is relevant, since most respondents who buy wine expressed their willingness to buy wine from Rowan berries. Organoleptic evaluation was carried out by the profile method and the method of point scales. Found that wine made from Rowan has a brown color with extracted fruit flavors, moderate alcohol content, balanced sweetness and velvety tannins. The taste of wine is characterized as fresh, moderate and harmonious, with a long pleasant aftertaste. According to chemical indicators (volume fraction of ethyl alcohol in table fruit wines, mass concentration of sugars, mass concentration of titratable acids in terms of malic acid, mass concentration of residual extract) wine fully complies with the requirements of the standard for table wines semi-dry. Changes in the content of vitamin $C$ in wine during storage are considered. It is shown that the wine contains a significant amount of vitamin $C$. 
Based on the conducted researches it is established that during the first 6 months of wine storage the content of vitamin $C$ is rather high. During subsequent storage, the content of vitamin $C$ is sharply reduced and is about $1 \%$ of the original. The studies suggest that the introduction of the developed technology will be cost-effective and will saturate the market of Kamchatka with natural wines from local raw materials.

\section{Введение}

В последние годы значительно выросло производство вин в Российской Федерации [1]. Рост происходит, в основном, за счет использования импортных виноматериалов, так как собственная сырьевая база в настоящее время значительно отстает от потребностей промышленности $[2,3]$.

Большая часть территории Российской Федерации не пригодна для виноделия, что приводит к дефициту отечественных виноматериалов. Решить эту проблему возможно за счет роста производства плодово-ягодных вин из местного сырья. Следует отметить, что производство плодово-ягодных вин в основном ограничено европейской частью России, что негативно влияет на ценообразование напитков (в сторону их повышения) в других регионах [4], в частности в Камчатском крае.

В распоряжении Правительства Российской Федерации «Об утверждении Стратегии развития пищевой и перерабатывающей промышленности РФ» [5] отмечена необходимость расширения отечественной продукции с учетом региональных особенностей рынка и потребительских предпочтений. При анализе литературных источников установлено, что на территории Камчатского края полностью отсутствует производство вин на основе растительного сырья. В то же время сырьевая база Камчатки обширна и включает ягодное сырье (дикорастущее и садовое).

Вероятно, ягоды, в изобилии произрастающие на территории Камчатки, вполне подходят для производства плодово-ягодных вин. Так, рябина бузинолистная (Sorbus sambucifolia) распространена по всей Камчатке. Это кустарник высотой до 2-х метров; плоды его сочные, ярко-красные, кислые, с приятным вкусом. Цветет рябина в июне - июле, плодоносит в сентябре - октябре.

Продуктивность ягод рябины бузинолистной изменчива по годам и зависит как от внутренних (популяционных), так и от внешних, главным образом погодных факторов. Рябинники относятся к группе ягодников с устойчивым плодоношением и относительно частыми хорошими и обильными урожаями. Биологический запас ягод рябины бузинолистной на Дальнем Востоке ориентировочно оценивается в 4,5 тыс. тонн $[6,7]$, в т.ч. 1,5 тыс. тонн в производственном фонде. Среднегодовой фактический сбор составляет 150 тонн; степень освоения от возможного сбора в производственном фонде составляет не более $12,5 \%$. Камчатка относится к основным регионам Дальнего Востока, доступным для промысловых заготовок ягод рябины бузинолистной.

Плоды рябины содержат яблочную, лимонную, винную и янтарную кислоты, дубильные и пектиновые вещества, сорбозу, глюкозу, фруктозу, сахарозу, сорбит, сорбиновую кислоту, аминокислоты, эфирные масла, соли калия, кальция, магния, натрия, железа, марганца, меди. Богаты плоды рябины витамином С и каротином [8]. Плоды используют в медицине в качестве поливитаминного средства и каротиносодержащего сырья. Флавоноиды, органические кислоты очень полезны для пищеварения. Сорбиновая кислота обладает бактерицидными свойствами, и поэтому ее применяют при консервировании. В семе- 
нах рябиновых ягод содержится до $20 \%$ жирных масел. Заготавливают рябину в сушеном, мороженом виде.

Плоды рябины применяют в свежем и сушеном виде как лечебное и профилактическое средство при цинге и других авитаминозах. Они входят в состав витаминных сборов. Народная медицина плоды рябины в виде настоев, отваров использует в качестве мочегонного, кровоостанавливающего, легкого слабительного и улучшающего аппетит средства. Плоды и свежий сок рябины используются при дизентерии, цинге. Зрелые плоды употребляются при атеросклерозе, гипертонической и мочекаменной болезнях.

В качестве сырья для производства вина предложено использовать рябину бузинолистную, растущую практически только на Камчатке, Курилах и Сахалине. Запасы рябины являются достаточно обширными в Камчатском крае, а сами ягоды характеризуются богатым набором витаминов, микро- и макроэлементов.

Цель работы - разработка технологии вина из плодов рябины бузинолистной. Для достижения цели были поставлены следующие задачи:

- изучить потребительский спрос населения г. ПетропавловскаКамчатского на вино из камчатского сырья;

- разработать технологию производства вина;

- изучить показатели качества вина из ягод рябины бузинолистной.

\section{Материалы и методы исследования}

Объектами исследований служили рябина бузинолистная (Sorbus sambucifolia), вспомогательные материалы, виноматериалы из рябины, а также технология производства вина из рябины бузинолистной. Плоды рябины бузинолистной были собраны в Елизовском районе Камчатского края в сентябре 2017 г.

Для проведения исследований использовались аналитические, химические, органолептические методы анализа. Экспериментальные исследования проведены в лаборатории кафедры «Технологии пищевых производств» Камчатского государственного технического университета. Отбор проб винных продуктов проводили согласно ГОСТ 31730-2012 «Продукция винодельческая. Правила приемки и методы отбора проб» [9].

Для определения органолептических показателей применяли описательный метод и метод, основанный на применении профильного метода по ГОСТ ISO 13299-2015 «Органолептический анализ. Методология. Общее руководство по составлению органолептического профиля» [10]. Химико-технологические параметры винных продуктов (объемную долю этилового спирта, массовую концентрацию сахаров, массовую концентрацию титруемых кислот в пересчете на яблочную кислоту, массовую концентрацию остаточного экстракта) исследовали согласно «Методам технохимического контроля в виноделии» [11].

При проведении всех исследований для обработки полученных данных применяли методы статистической и графоаналитической обработки. Статистическую обработку результатов осуществляли на основе подсчета средних значений величин и стандартной средней ошибки. Для получения достоверных результатов проводился подсчет необходимого количества параллельно проводимых определений. Цифровые величины, указанные в таблице, представляют собой арифметическое среднее с надежностью Р 0,95. 


\section{Оценка показателей качества вина из ягод рябины бузинолистной}

Исследование потребительского спроса является важным фактором налаживания производства. Для проведения исследований была разработана анкета, ответы на которую должны были позволить сделать вывод о востребованности у потребителей г. Петропавловска-Камчатского вина из растительного сырья Камчатского края, в частности ягод рябины бузинолистной. Анкета включала в себя демографическую часть (возраст и пол), а также содержательную часть, которая позволила изучить предпочтения потребителей и востребованность вина на рынке.

Авторами был проведен социологический опрос потребителей. Около половины респондентов (48\%) ответило, что покупают вино в торговой сети г. Петропавловска-Камчатского, причем подавляющее большинство ответило, что покупает вино реже 1 раза в месяц. Среди респондентов, положительно ответивших на вопрос «Покупаете ли Вы вино?», подавляющее большинство (95\%) отметили, что будут покупать вино из ягод рябины камчатской или возьмут на пробу. Такие же результаты получены при ответе на вопрос «Будете ли Вы покупать вина из камчатского сырья (в частности из ягод камчатской рябины)?» (рис. 1).

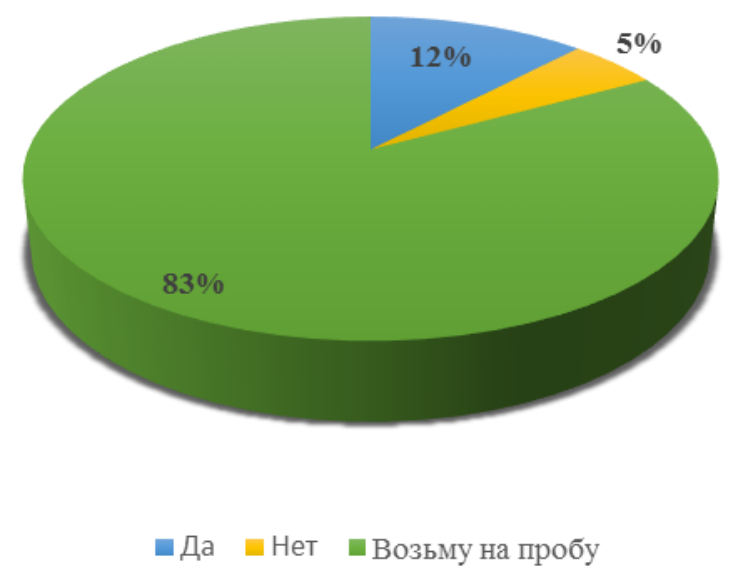

Puc.1. Распределение ответов респондентов на вопрос анкеты «Будете ли Вы покупать вина

из камчатского сырья (в частности из ягод камчатской рябины)»

Источник: составлено автором

При этом практически все респонденты (94\%) заявили, что для них имеет значение присутствие в составе вина натуральных ингредиентов, в том числе камчатских, а также высокое содержание биологически-активных веществ.

Таким образом, проведенные исследования позволили установить, что разработка технологии вина из камчатского сырья актуальна, так как подавляющее большинство респондентов, покупающих вино, выразили готовность купить вино из ягод рябины. При этом большинство потребителей положительно относятся к вину из местного сырья с высоким содержанием биологическиактивных веществ. 
Результаты опроса подтверждает актуальность проводимого исследования, направленного на рациональное использование растительного сырья Камчатского края. Разработка технологии вина из рябины бузинолистной позволит расширить ассортимент производимой в крае продукции повышенной биологической ценности.

С целью разработки технологии производства вина были произведены опытные партии вина из рябины бузинолистной. В качестве вспомогательных материалов при изготовлении вина использовали кристаллический сахар по ГОСТ 33222-2015 «Сахар белый. Технические условия» [12] и воду питьевую по СанПиН 2.1.4.1074-01 «Питьевая вода. Гигиенические требования к качеству воды централизованных систем питьевого водоснабжения» [13]. Необходимо было добиться максимального извлечения дубильных, красящих, ароматических, вкусовых и бродильных веществ из ягодного сырья. Так как рябина содержит незначительное количество сока, ягоды рябины перетирали и смешивали с водой.

Изначально целью проводимых исследований была разработка технологии производства вин исключительно из камчатского сырья, в связи с этим необходимо было исследовать бродильную активность микрофлоры ягод рябины. При установлении низкой бродильной активности возникала бы необходимость внесения дополнительных культур винных дрожжей. Для изучения бродильной активности измельченные ягоды рябины заливали водой с предварительно растворенным в ней сахаром. Брожение проводили при температуре 20$24^{\circ} \mathrm{C}$. В процессе исследований было установлено, что микрофлора ягод рябины бузинолистной обладает достаточной бродильной активностью, что делает возможным процесс брожения без использования дополнительных дрожжевых материалов.

На рис. 2 приведена разработанная в результате исследований технологическая схема.

Важную роль в оценке качества вин играет дегустация. При проведении исследований по разработке технологии вина одним из основных критериев качества являлась органолептическая оценка. Основными характерными признаками вина являются крепость, кислотность, сладость, терпкость, полнота, обусловленные наличием нелетучих соединений. Так, кислый вкус вызывается кислотами и их солями в составе вина, полнота вкуса определяется наличием углеводов, многоатомных спиртов, органических кислот, азотистых, фенольных, минеральных веществ. Наличие в вине спирта оказывает влияние на восприятие других вкусовых признаков. Сладкий вкус обусловлен наличием монои дисахаридов, терпкий - фенольными соединениям, в основном танинами [14].

Аромат вина, как известно, определяется испаряющимися с его поверхности летучими соединениями различного происхождения, в состав которых входят как собственные вещества ягоды, так и продукты спиртового брожения, вещества, образующиеся в процессе технологической обработки, а также образующиеся при хранении в результате сложных химических и биохимических процессов [15]. Сложность химического состава вин затрудняет объективную оценку органолептических качеств. 


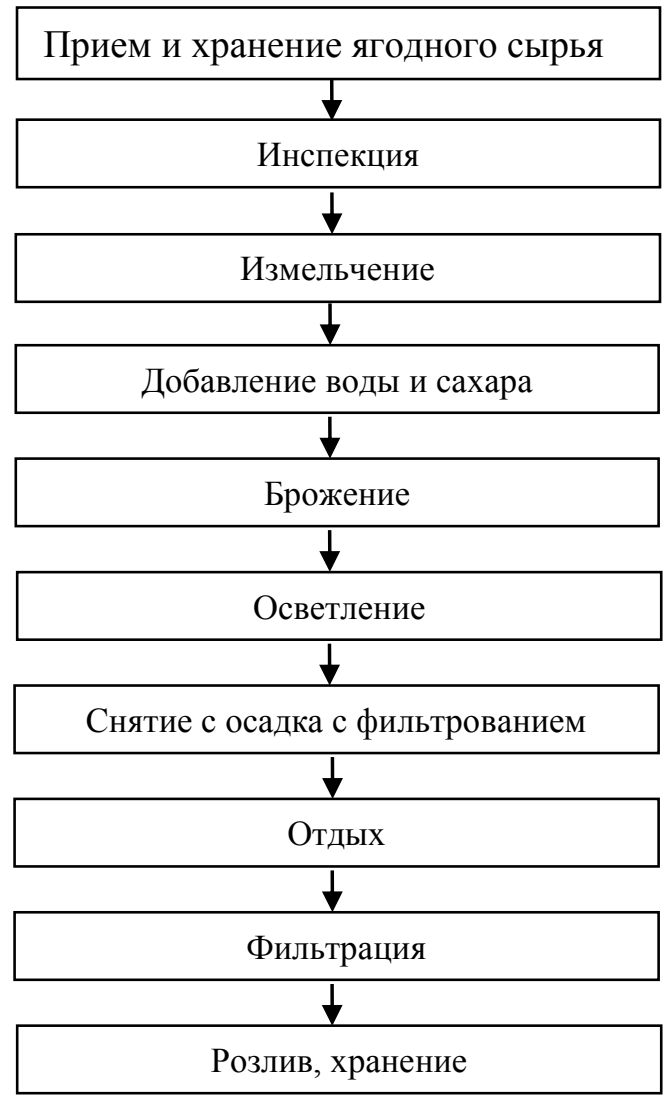

Puc. 2. Технологическая схема производства вина из ягод рябины бузинолистной Источник: составлено автором

Исходя из вышесказанного, органолептическую оценку вина из ягод рябины бузинолистной (рис. 3) с целью максимальной объективности проводили двумя способами: профильным методом и описательным (табл. 1). Была разработана 10-балльная шкала для оценки органолептических показателей профильным методом (табл. 2). Результаты органолептических исследований с помощью профилограмм приведены на рис. 4-6.

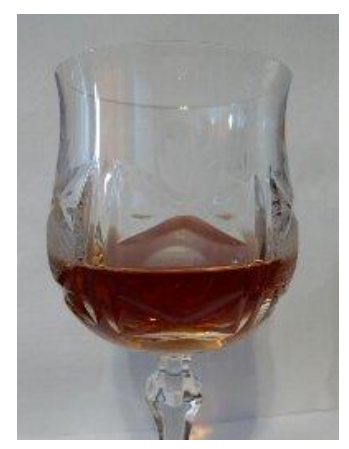

Puc. 3. Внешний вид вина из ягод рябины бузинолистной Источник: составлено автором 
Таблица 1

Органолептические показатели вина из ягод рябины бузинолистной

\begin{tabular}{|c|c|c|c|c|}
\hline \multicolumn{5}{|c|}{ Наименование показателя } \\
\hline Прозрачность & Окраска & Aромат & Bкyc & Общее сложение \\
\hline $\begin{array}{c}\text { Кристаллически- } \\
\text { прозрачное }\end{array}$ & $\begin{array}{c}\text { Интенсивный } \\
\text { коричневый цвет }\end{array}$ & $\begin{array}{c}\text { Развитый, уме- } \\
\text { ренно плодовый с } \\
\text { ароматом рябины, } \\
\text { свежий, чистый, } \\
\text { без дефектов }\end{array}$ & $\begin{array}{c}\text { Умеренный плодовый } \\
\text { с умеренной спиртуоз- } \\
\text { ностью, свежий пол- } \\
\text { ный вкус, гармонично } \\
\text { сладкий с мягким } \\
\text { терпким привкусом, с } \\
\text { приятным послевкуси- } \\
\text { ем, без дефектов }\end{array}$ & Хорошее качество \\
\hline \multicolumn{5}{|c|}{ Средний балл } \\
\hline 0,5 & 0,5 & 2,5 & 4,5 & 8 \\
\hline
\end{tabular}

Источник: составлено автором

Вино из рябины кристаллически-прозрачное, коричневого цвета, с умеренным плодовым вкусом, умеренной спиртуозностью, гармоничной сладостью и бархатистой терпкостью. Из рис. 5 следует, что вино из рябины бузинолистной имело развитый, умеренно плодовый аромат рябины, свежий и чистый. Профилограмма вкусового комплекса напитка показана на рис. 6. Вкус характеризовался как свежий и полный, с мягким терпким привкусом и долгим приятным послевкусием, без дефектов. При этом вкус не имел отрицательных для потребителя свойств. В целом вино оценено как выдержанное хорошего качества, с развитым букетом выдержки.

Таблииа 2

Шкала оценки органолептических показателей вина профильным методом

\begin{tabular}{|c|c|c|}
\hline Показатель & Словесная характеристика балов & Балл \\
\hline \multirow{5}{*}{ Прозрачность } & Кристаллическое вино & 10 \\
\hline & Чистое с блеском & 8 \\
\hline & Без блеска & 6 \\
\hline & С опалесценцией & 4 \\
\hline & Мутное & 2 \\
\hline \multirow{5}{*}{ Окраска } & Типичная, интенсивно-коричневая & 10 \\
\hline & С небольшими отклонениями от нормального & 8 \\
\hline & Со значительными отклонениями & 6 \\
\hline & Не типичная & 4 \\
\hline & Грязный тон в окраске & 2 \\
\hline \multirow{5}{*}{ Аромат } & Очень тонкий и развитый букет, соответствующий типу вина & 10 \\
\hline & Хорошо развитый & 8 \\
\hline & Слабо развитый & 6 \\
\hline & Не соответствующий типу и возрасту & 4 \\
\hline & $\mathrm{C}$ посторонними тонами & 2 \\
\hline \multirow{5}{*}{ Вкус } & Тонкий, гармоничный, соответствующий тону и возрасту & 10 \\
\hline & Гармоничный & 8 \\
\hline & Гармоничный, но мало соответствующий типу & 6 \\
\hline & Ординарный & 4 \\
\hline & $\mathrm{C}$ посторонними тонами & 2 \\
\hline \multirow{5}{*}{ Общее впечатление } & Исключительно высокое качество & 10 \\
\hline & Хорошее качество & 8 \\
\hline & Удовлетворительное качество & 6 \\
\hline & Среднее качество & 4 \\
\hline & Дефектное & 2 \\
\hline
\end{tabular}

Источник: составлено автором 


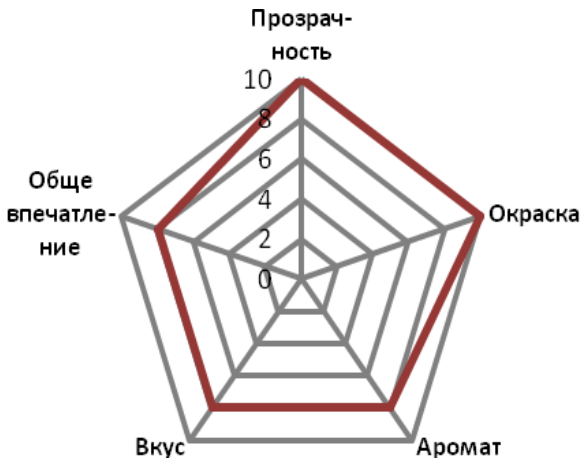

Puc. 4. Профилограмма органолептических показателей вина из ягод рябины бузинолистной

Источник: составлено автором

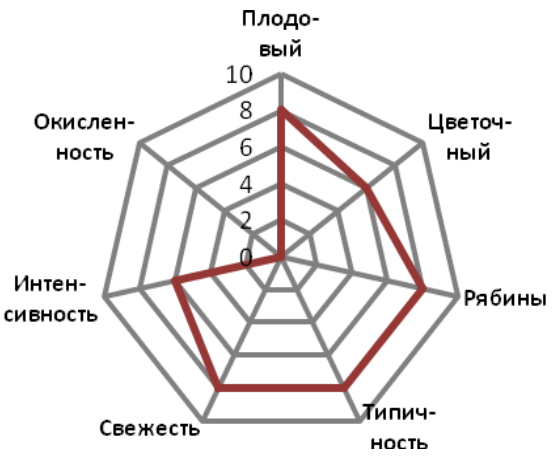

Puc. 5. Профилограмма аромата вина из ягод рябины бузинолистной Источник: составлено автором

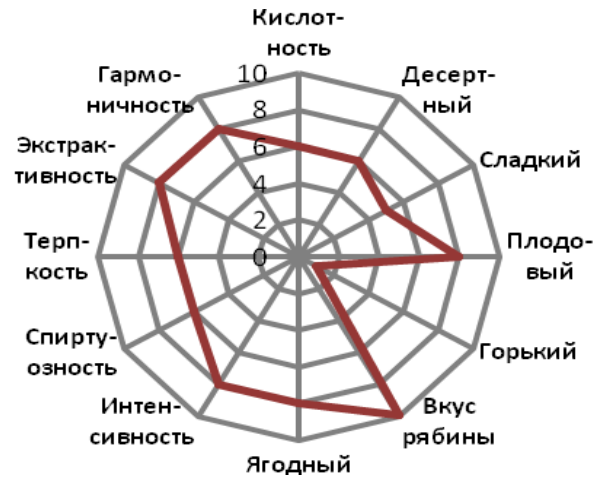

Рuc. 6. Профилограмма вкуса вина из ягод рябины бузинолистной Источник: составлено автором 
В готовом вине из рябины бузинолистной исследовали показатели качества, такие как объемная доля этилового спирта, массовая концентрация сахаров, массовая концентрация титруемых кислот в пересчете на яблочную кислоту, массовая концентрация остаточного экстракта. Было показано, что все они отвечают требованиям ГОСТ 33806-2016 «Вина фруктовые столовые и виноматериалы фруктовые столовые» [16] по химическим характеристикам (табл. 3).

Химические показатели вина из рябины бузинолистной

Таблица 3

\begin{tabular}{|l|c|c|}
\hline \multicolumn{1}{|c|}{ Наименование показателя } & Норма по ГОСТ 33806-2016 & $\begin{array}{c}\text { Значения показателя в вине } \\
\text { из рябины бузинолистной }\end{array}$ \\
\hline $\begin{array}{l}\text { Объемная доля этилового спирта } \\
\text { в столовых фруктовых винах, \% }\end{array}$ & Не менее 6,0 и не более 15,0 & $13,0 \pm 1,0$ \\
\hline $\begin{array}{l}\text { Массовая концентрация сахаров } \\
\text { в полусухих винах, г/дм }\end{array}$ & Более 4,0 и менее 30,0 & $5,0 \pm 1,0$ \\
\hline $\begin{array}{l}\text { Массовая концентрация титруе- } \\
\text { мых кислот в пересчете на яб- } \\
\text { лочную кислоту, г/дм }\end{array}$ & Не менее 4,0 & $8,1 \pm 0,04$ \\
\hline $\begin{array}{l}\text { Массовая концентрация остаточ- } \\
\text { ного экстракта, г/дм }\end{array}$ & Не менее 10,0 & $46,7 \pm 0,7$ \\
\hline
\end{tabular}

Источник: составлено автором

Установлено, что вино из рябины отличается высокой экстрактивностью (массовая доля остаточного экстракта составила 46,7 г/дм $^{3}$ ) и значительной спиртуозностью (массовая доля этилового спирта равнялась 13,0\%). Массовая концентрация титруемых кислот составила $8,1 \pm 0,04$ г/дм ${ }^{3}$, что соответствует норме ГОСТ 33806-2016. Кислотность вина обусловлена органическими кислотами, поступающими с ягодным сырьем. Кислоты придают вину специфический вкус [17]. Повышенное содержание в вине кислот, особенно яблочной, обусловливает резкость во вкусе. Органические кислоты и продукты их взаимодействия (эфиры и др.) играют важную роль в формировании органолептических свойств вин. Кислоты также влияют на предотвращение бактериальных заболеваний и стабильность вин [14].

Массовая концентрация сахаров в вине составила $5,0 \pm 1,0$ г/дм ${ }^{3}$, что соответствует требованиям стандарта к полусухим винам - более 4,0 и менее 30,0 $\Gamma /$ дм$^{3}$. Как известно, сахара и продукты их реакций имеют значительное влияние на вкус, цвет, аромат и стабильность вин. В процессе созревания и старения вин сахара претерпевают сложные изменения.

В вине также были проведены исследования содержания витамина $\mathrm{C}$ (рис. 7). Массовую долю витамина С определяли йодатным методом по ГОСТ 7047-55 [18].

Установлено, что первые полгода в вине сохраняется стабильно высокое содержание витамина С. Так в вине рябиновом по истечении 3 месяцев хранения содержание витамина С составляло 175,0 мг\%. Таким образом, в $100 \mathrm{~cm}^{3}$ вина из рябины бузинолистной, изготовленного по разработанной технологии, содержится $195 \%$ от суточной потребности взрослого человека в этом витамине [19]. После 4 месяцев хранения происходит интенсивный распад витамина С в вине - его содержание снижается до 70,2 мг\%, что тоже значительно 
(78\% от суточной потребности). За последующий месяц происходит распад половины содержащегося в вине витамина $\mathrm{C}$, и тем не менее его количество попрежнему остаются существенным $(35,1$ мг\%). Как известно, витамин С участвует в окислительно-восстановительных реакциях, функционировании иммунной системы, способствует усвоению железа. Этот витамин не накапливается в организме и необходимо его регулярное поступление. Дефицит витамина С приводит к рыхлости и кровоточивости десен, носовым кровотечениям вследствие повышенной проницаемости и ломкости кровеносных капилляров. В России среднее потребление составляет от 55 до $80 \%$ от физиологической потребности. Проведенные исследования показывают, что употребление рябинового вина в первые полгода после его производства позволяет значительно покрыть потребности организма в этом витамине.

При более длительном хранении (до года) содержание витамина $\mathrm{C}$ значительно снижается. Так, через 11 месяцев массовая доля витамина $\mathrm{C}$ в вине составляет 2,3 мг\% ( $2 \%$ от суточной потребности). При последующем хранении содержание витамина С стабильно и составляет 2,1 мг\%.

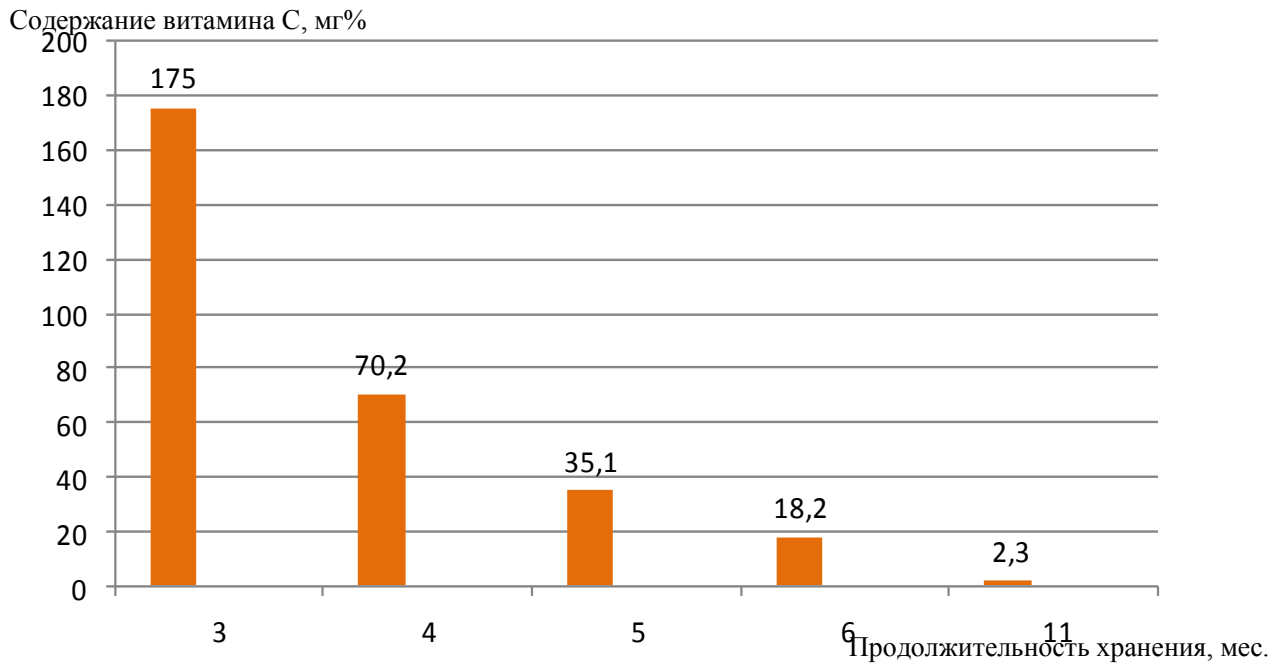

Рис. 7. Содержание витамина С в вине из рябины бузинолистной Источник: составлено автором

На основании проведенных исследований установлено, что в течение первых 6 месяцев хранения вина содержание витамина С достаточно высокое. При последующем хранении содержание витамина С резко снижается и составляет около $1 \%$ от первоначального.

Таким образом, на основании проведенных исследований разработана технология производства вина из рябины бузинолистной. Полученное вино имеет хорошие органолептические показатели (прозрачность, цвет, аромат, вкус). Установлено, что по химическим показателям (объемная доля этилового спирта в столовых фруктовых винах, массовая концентрация сахаров, массовая концентрация титруемых кислот в пересчете на яблочную кислоту, массовая концентрация остаточного экстракта) вино полностью соответствует требованиям ГОСТ 33806-2016 «Вина фруктовые столовые и виноматериалы фруктовые столовые» к винам столовым полусухим. Показано, что вино содержит 
значительное количество витамина С. Так, первые 3 месяца хранения содержание витамина С в $100 \mathrm{~cm}^{3}$ вина составляет $195 \%$ от потребности человека в этом витамине.

\section{Заключение}

Таким образом, впервые разработана технология вина из рябины бузинолистной, произрастающей практически только на Камчатке, Курилах и Сахалине. Доказано, что полученное из рябины бузинолистной вино имеет хорошие органолептические показатели (прозрачность, цвет, аромат, вкус). Установлено, что по химическим показателям (объемная доля этилового спирта в столовых винах, массовая концентрация сахаров, массовая концентрация титруемых кислот в пересчете на яблочную кислоту, массовая концентрация остаточного экстракта) вино полностью соответствует требованиям ГОСТ 33806-2016 «Вина фруктовые столовые и виноматериалы фруктовые столовые» к винам столовым полусухим. Показано, что вино содержит значительное количество витамина С.

Надо отметить, что на территории Камчатского края полностью отсутствует производство вин, в том числе из местного сырья, что отражается также на ценообразовании. Вышесказанное позволяет предположить, что внедрение разработанной технологии будет рентабельным и позволит насытить рынок Камчатки натуральными винами из местного сырья. На основании разработанной технологии возможно производство полусухого вина из рябины бузинолистной.

\section{Список источников / References}

1. Оганесянц Л.А. Виноградарство и виноделие в Российской Федерации // Виноделие и виноградарство. 2011. № 1. С. 4-7. [Oganesyancz L.A. Vinogradarstvo i vinodelie v Rossijskoj Federacii [Viticulture and winemaking in the Russian Federation]. Winemaking and viticulture, 2011, no. 1, P. 4-7.]

2. Оганесянц Л.А. Состояние и перспективы развития виноградарства и виноделия в России // Виноделие и виноградарство. 2010. № 1, С. 4-5. [Oganesyancz L.A. Sostoyanie i perspektivy` razvitiya vinogradarstva i vinodeliya $\mathrm{v}$ Rossii [State and prospects of development of viticulture and winemaking in Russia]. Winemaking and viticulture, 2010, no. 1, pp. 4-5].

3. Хиабахов Т.С. О насущных проблемах виноделия России // Виноделие и виноградарство. 2007. № 1. С. 4-7. [Hiabahov T.S. O nasushhny`x problemax vinodeliya Rossii [On the pressing problems of winemaking in Russia]. Winemaking and viticulture, 2007, no. 1, pp. 4-7].

4. Салмин А.А. Обоснование и разработка технологии вин и винных напитков из плодово-ягодного сырья Дальнего Востока: дис. ... канд. техн. наук. Владивосток, 2012. 171 c. [Salmin A.A. Obosnovanie I razrabotka tekhnologii vin I vinnyh napitkov iz plodovo-yagodnogo syr ya Dal’nego Vostoka: Dis. kand. tehn. nauk [The substantiation and development of the technology of wines and wine drinks from fruit and berry raw materials of the Far East. Cand. Dis.(Tech.)]. Vladivostok, 2012. 171 p.].

5. Об утверждении Стратегии развития пищевой и перерабатывающей промышленности Российской Федерации: распоряжение Правительства РФ от 17 апреля 2012 года № 559-p. [Ob utverzhdenii razvitia pishchevoj i pererabatyvayushchej promyshlennosti Rossijskoj Federacii: rasporyazhenie pravitel'stva RF ot 17 aprelya 2012 goda \# 559-r [On approval of the strategy for the 
development of food processing and processing industry of the Russian Federation]] Available at: http://docs.cntd.ru/document/902343994 (accessed 18.04.2018).

6. Сухомиров Г.И., Измоденов А.Г. Недревесные растительные ресурсы Дальнего Востока и их освоение // Экономическая жизнь Дальнего Востока. 1995. № 1. C. 102-115. [Suhomirov G.I., Izmodenov A.G. Nedrevesnye rastitel'nye resursy Dal'nego Vostoka $i$ ih osvoenie [Non-timber vegetable resources of the Far East and their development]. Economic Life of the Far East, 1995, no.1, pp. 102-115].

7. Нечаев А.А. Продуктивность и ресурсы ягод брусники, черники пазушной и рябины бузинолистной на Дальнем Востоке // Современные проблемы природопользования, охотоведения и звероводства. Международная научнопрактическая конференция. 2007. С. 315-316. [Nechaev A.A. Productivnost' I resursy yagod brusniki, cherniki pazushnoj I ryabiny buzinolistnoj na Dal'nem Vostoke [Productivity and recources of the berries of lingonberry, biberry and mountain ash of elderberry in the Far East]. Sovremenye problemy prirodopol'zovania, ohotovedenia i zverovodstva. Mezhdunarodnaya nauchnoprakticheskaya konferenciya [Current problems of triodusage, hunting and animal breeding. International Scientific - Practical Conference]. 2007, pp. 315-316.]

8. Якубов В.В., Чернягина О.А. Дикорастущие хозяйственно полезные растения Камчатки // Труды Камчатского института экологии и природопользования ДВО РАН. 2000. Вып. 1. С. 259-279. [Yakubov V.V., Chernyagina O.A. Dikorastushhie xozyajstvenno polezny`e rasteniya Kamchatki [Wild economically useful plants of Kamchatka]. Proceedings of the Kamchatka Institute of ecology and environmental Sciences Feb RAS, 2000, no. 1, pp. 259-279].

9. ГОСТ 31730-2012. Продукция винодельческая. Правила приемки и методы отбора проб [GOST 31730-2012. Produkciya vinodel'cheskaya. Pravila priemki i metody otbora prob [Wine production. Acceptance rules and sampling methods]] Available at: http://docs.cntd.ru/document/1200098768 (accessed 12.12.2018).

10. ГОСТ ISO 13299-2015. Органолептический анализ. Методология. Общее руководство по составлению органолептического профиля [GOST ISO 132992015. Organolepticheskij analiz. Metodologiya. Obshchee rukovodstvo po sostavleniyu organolepticheskogo profilya [Organoleptic analysis. Methodology. General guidelines for the preparation of organoleptic profile]] Available at: http://docs.cntd.ru/document/1200098768 (accessed 12.12.2018).

11. Гержикова В.Г., ред. Методы технохимического контроля в виноделии. Симферополь: Таврида, 2002. 260 с. [Gerzhikova V.G., eds. Metody tekhnohimicheskogo kontrolya $\mathrm{v}$ vinodelii [Methods of technochemical control in winemaking] Simferopol'. Tavrida, 2002. 260 p.]

12. ГОСТ 33222-2015. Сахар белый. Технические условия [GOST 33222-2015. Sahar belyj. Tekhnicheskie usloviya [Sugar white. Technical conditions]] Available at: http://docs.cntd.ru/document/1200098768 (accessed 12.12.2018).

13. СанПиН 2.1.4.1074-01. Питьевая вода. Гигиенические требования к качеству воды централизованных систем питьевого водоснабжения. Контроль качества [SanPiN 2.1.4.1074-01. Pit'evaya voda. Gigienicheskie trebovaniya $\mathrm{k}$ kachestvu vody centralizovannyh sistem pit'evogo vodosnabzheniya. Kontrol' kachestva [Drinking water. Hygienic requirements to water quality of centralized drinking water supply systems. Quality control]] Available at: http://docs.cntd.ru/document/1200098768 (accessed 12.12.2018).

14. Кишковский 3.Н., Скурихин И.М. Химия вина: учебник для вузов. - 2-е изд. М.: ВО Агропромиздат, 1988. 251 с. [Kishkovskij Z.N., Skurihin I.M. Himiya vina: uchebnik dlya vuzov 2-e izd. [Chemistry of wine: textbook for universities] Moscow. VO Agropromizdat Publ., 1988. 251 p.] 
15. Баланов П.Е., Смотраева И.В. Промышленное производство вина. Ч. 2: учеб. пособие для вузов. СПб.: Университет ИТМО, 2016. 82 с. [Balanov P.E., Smotraeva I.V. Promyshlennoe proizvodstvo vina. CH. 2: ucheb. posobie dlya vuzov [Industrial wine production] SPb. Universitet ITMO Publ., 2016. 82 p.]

16. ГОСТ 33806-2016. Вина фруктовые столовые и виноматериалы фруктовые столовые [GOST 33806-2016. Vina fruktovye stolovye i vinomaterialy fruktovye stolovye [Wines, fruit, table and wine materials, fruit, table] Available at: http://docs.cntd.ru/document/1200098768 (accessed 12.12.2018).

17. Подкорытов А.Г., Кадникова И.А., Подкорытова Е.А. Разработка технологии сухого концентрата напитка на основе пектина из морской травы // Известия ДВФУ. Экономика и управление. 2018. № 2. С. 156-168. [Podkorytov A.G., Kadnikova I.A., Podkorytova E.A. Razrabotka tekhnologii suhogo koncentrata napitka na osnove pektina iz morskoj travy [Разработка технологии сухого концентрата напитка на основе пектина из морской травы] Proceedings of the University. Economics and management. 2018. no. 2. pp. 156-168].

18. ГОСТ 7047-55. Витамины А, С, Д, В 1 , В 2 и РР. Отбор проб, методы определения витаминов и испытания качества витаминных препаратов [GOST 7047-55. Vitaminy A, S, D, V1, V2 i RR. Otbor prob, metody opredeleniya vitaminov i ispytaniya kachestva vitaminnyh preparatov [Vitamins a, C, D, B1, B2 and PP. Sampling, methods for determination of vitamins and quality test of vitamin preparations]] Available at: http://docs.cntd.ru/document/1200098768 (accessed 12.12.2018).

19. Методические рекомендации 2.3.1.2432-08 «Нормы физиологических потребностей в энергии и пищевых веществах для различных групп населения Российской Федерации» [Metodicheskie rekomendacii 2.3.1.2432-08 «Normy fiziologicheskih potrebnostej v ehnergii i pishchevyh veshchestvah dlya razlichnyh grupp naseleniya Rossijskoj Federacii» [Methodical recommendations 2.3.1.2432-08 " Norms of physiological needs for energy and nutrients for various groups of the population of the Russian Federation»]] Available at: http:// docs.cntd.ru/document/1200076084 (accessed 18.04.2018).

\section{Сведения об авторах / About authors}

Благонравова Майя Владимировна, кандидат технических наук, доцент, доцент кафедры «Технологии пищевых производств», Камчатский государственный технический университет. 683003 Россия, г. Петропавловск-Камчатский, ул. Ключевская, 35.

E-mail: mblagonravova@mail.ru

Maya V. Blagonravova, Candidate of Technical Sciences, Associate Professor, Associate Professor of the Department of Food Production Technologies, Kamchatka State Technical University. 35, Klyuchevskaya str., Petropavlovsk-Kamchatsky, Russia 683003. E-mail: mblagonravova@mail.ru 